\title{
ESSENTIAL OIL COMPOSITION AND ANTIMICROBIAL ACTIVITY OF FRUITS OF Iryanthera ulei W. FROM COLOMBIA
}

\author{
LUIS E CUCA*, FREDDY A BERNAL, CARLOS A COY, ERICSSON D COY \\ Universidad Nacional de Colombia, Facultad de Ciencias, Departamento de Química, Laboratorio de Investigación en \\ Productos Naturales Vegetales, Cra 30 45-03, A.A. 14490, Bogotá, Colombia
}

(Received: December: 5, 2008 - Accepted: July 27, 2009)

\begin{abstract}
The essential oil was obtained by steam distillation from fruits of Iryanthera ulei Warb. growing in Colombia. The oil was analyzed by GC/FID and GC/ MS. The main components were $\alpha$-muurolol (13.2\%), spathulenol (12.1\%), $\alpha$-cadinol (7.8\%), guaiol (4.0\%), oplopanone (3.7\%), 1,10-diepi-cubenol (3.4\%) and limonene (3.3\%) constituting a sesquiterpene-type enriched mixture. In addition, oil was tested for its antimicrobial activity against some Gram-positive and Gramnegative bacteria by means of a modified agar-well diffusion method. S. aureus strain was found to be the most sensitive microorganism.
\end{abstract}

Keywords Iryanthera ulei, Myristicaceae, essential oil composition, $\alpha$-muurolol, spathulenol, antimicrobial activity.

\section{INTRODUCTION}

Iryanthera ulei Warb. is a tree which grows up to $30 \mathrm{~m}$ in height. The fruit has a perianth carnous or thin carnous, often glabrescent, cupuliform, around 3 $\mathrm{mm}$ long $^{1}$ and it grows in the wild in Amazonian Brazil, Venezuela, Colombia and Peru. I. ulei has been used by some Colombian natives, like Barasana tribe that uses it to clean infected wounds and Puinave tribe as baiting fish. ${ }^{2}$ In addition, this plant is traditionally used to treat diarrhea, oral infections, malaria and anemia, ${ }^{3}$ as well as, other Iryanthera species has been described as useful for treating infected wounds ${ }^{4}$ and fever. ${ }^{5}$

Previous studies of $I$. ulei revealed the presence of diarylpropanes, flavonoids, butanolides and neolignans together with one flavonolignoid from extracts of both trunk wood and bark. ${ }^{6-8}$ However, to the best of our knowledge there are no previous both chemical and biological activity investigations on the volatile components of I. ulei.

The most of the essential oil from plants exhibited significant biological activities, such as antimicrobial, ${ }^{9}$ antioxidant ${ }^{10}$ among others. ${ }^{11}$ Therefore, the aim of this paper is to determine the essential oil composition of fruit of this Myristicaceae species growing in Colombia and its antimicrobial activity against Gram-positive and Gram-negative bacteria by means of a modified agar-well diffusion assay.

\section{EXPERIMENTAL}

\section{Plant Material}

Fruits of I. ulei were collected in Vereda Bajo Brasil, Florencia municipality (Caquetá, Colombia) in February 2006. A voucher specimen, numbered COL519611, has been deposited at the Herbario Nacional Colombiano of the Instituto de Ciencias Naturales - Universidad Nacional de Colombia.

Essential oil extraction

The fruits $(1234 \mathrm{~g})$ of the freshly collected plant were finely chopped and steam distilled for $3 \mathrm{~h}$ to obtain $0,596 \mathrm{~g}$ essential oil. It was dried over anhydrous sodium sulfate.

Analysis of essential oil

Oil was analyzed by capillary GC and GC/MS. GC analysis was carried out on a HP 5890 series II gas chromatograph equipped with a FID and operated in split mode (1:15, injected volume, $1 \mu \mathrm{L})$, using a fused silica capillary column HP-5, $30 \mathrm{~m}$ x $0.25 \mathrm{~mm}, 0.5 \mu \mathrm{m}$ coating thickness. The operational conditions used were as follows: temperature program from $50^{\circ} \mathrm{C}(4 \mathrm{~min})$ to $300^{\circ} \mathrm{C}(20$ $\mathrm{min})$ at $4^{\circ} \mathrm{C} / \mathrm{min}$, split/splitless injector $\left(300^{\circ} \mathrm{C}\right)$, carrier gas was $1.0 \mathrm{~mL}$ of $\mathrm{He} /$ min; and makeup gas was nitrogen at a $30 \mathrm{~mL} / \mathrm{min}$ flow rate. Quantitation was by using the Class 5000 software. Percentages were calculated by electronic integration of FID, peak areas without the use of response factor correction. Retention indices (RI) were calculated to help identification by using linear hydrocarbons $\left(\mathrm{C}_{8}-\mathrm{C}_{24}\right)$.

GC/MS analyses were carried out on a Shimadzu GC-17A Gas Chromatograph coupled to a Shimadzu GCMS-QP5050A mass spectrometer ( $70 \mathrm{eV}$ ) using a fused silica capillary column HP-5ms, $30 \mathrm{~m}$ x $0.25 \mathrm{~mm}, 0.5 \mu \mathrm{m}$ coating thickness, with similar temperature programmed as in GC. Interface temperature $300^{\circ} \mathrm{C}$. Detector voltage: $1.20 \mathrm{kV}$. Acquisition mass range: $42-$ $800 \mathrm{u}$. Acquisition mode: full scan; scan interval: $0.35 \mathrm{~s}$. Solvent delay: 3 min.

The components of the oil were identified by comparison of their mass spectra with those of a computer library search and confirmed by comparison of their retention indices. ${ }^{12-14}$ The compounds identified on the oil are listed in Table 1.
Antibacterial assay

Bacterial strains. Gram-positive: Staphylococcus aureus ATCC 65380, Enterococcus faecalis ATCC 29212. Gram-negative: Escherichia coli ATCC 25922 and two Salmonella typhimurium strains: ATCC 14028s (mouse virulent smooth strain) and MS7953 (PhoP gene modified macrophage survival mutants strain). All strains were a gift from Professor E. A. Groisman of the Department of Molecular Microbiology at the University of Washington, St. Louis, MO, USA).

The antibacterial activity of the oil was tested by means of agar-well diffusion method modified from Lehrer et al. reported methodology. ${ }^{15}$ Briefly, the mid-logarithmic phase of bacteria was mixed uniformly in Trypticase soy agar plates at the concentration of $4 \times 10^{7} \mathrm{CFU} / \mathrm{ml}$. Small wells in $2-\mathrm{mm}$ in diameter were punched, followed by addition of essential oil. Following diffusion of oil into agar for $18 \mathrm{~h}$, the plates were overlayed with nutrient agar (Difco) and incubated overnight at $37^{\circ} \mathrm{C}$. Optical density (OD) of an aliquot was measured at $620 \mathrm{~nm}$ and, based on the relationship $\mathrm{OD} 0.20$ $=5 \times 10^{7} \mathrm{CFU} / \mathrm{mL}$, a volume containing 1 to $4 \times 10^{6} \mathrm{CFU}$ was added to 10 $\mathrm{mL}$ previously autoclaved, warm $10 \mathrm{~mL}$ buffer containing $3 \mathrm{mg}$ powdered TSB medium, $1 \% \mathrm{w} / \mathrm{v}$ low-electroendosmosis-type agarose (Sigma Chemical Co, Saint Louis, MO, USA) and a final concentration of $0.02 \% \mathrm{v} / \mathrm{v}$ Tween-20 (Sigma). The diameters of the bacterial clearance zones were recorded by a caliper. The results were reported as $0.1 \mathrm{~mm}$ of inhibition zone is equivalent to 1 Activity Unit (AU). These radial diffusion positive samples were tested for antibacterial activity in a quantitative assay. Bacterial inhibition was calculated in quantitative assays as being bacterial growth inhibition $\%=100 \times\left(\mathrm{OD}_{620}\right.$ bacteria in control - $\mathrm{OD}_{620}$ medium $)-\left(\mathrm{OD}_{620} \text { sample in test }-\mathrm{OD}_{620} \text { blank }\right)^{620} /$ $\left(\mathrm{OD}_{620}\right.$ bacteria in control $-\mathrm{OD}_{620}$ blank).

\section{RESULTS AND DISCUSSION}

The gas chromatogram of the I. ulei fruit volatiles showed 50 compounds, from which 39 were identified representing $80.5 \%$ (listed in table 1). The main compounds of the essential oil were $\alpha$-muurolol $(13.2 \%)$, spathulenol $(12.1 \%)$ and $\alpha$-cadinol (7.8\%). Furthermore, it was found the presence of eleven unknown compounds (17.8\%) including three components $(3.7 \%)$ possess a mass spectra profile that could be attributable to 1,2-dihydroxy1-methylalkanes $\left(\left[\mathrm{M}-\mathrm{C}_{2} \mathrm{H}_{5} \mathrm{O}\right]^{+} \mathrm{m} / \mathrm{z} 45(100)\right)$, and five components $(9.8 \%)$ which exhibit in the mass spectrum the characteristic peaks for oxygenated sesquiterpenes $\left([\mathrm{M}]^{+} \mathrm{m} / \mathrm{z} 220\right)$.

A review of the literature showed that no oil from any Iryanthera species has been studied yet. However, the oil composition of four Myristicaceae species has only been reported: Virola surinamensi ${ }^{16-17}$, Myristica fragrans ${ }^{18-20}$, Myristica malabarica ${ }^{21}$, and Gymnacranthera canarica ${ }^{21}$. Monoterpenes were the main constituents of two first American and Asian species (terpinen-4ol and $\alpha$-pinene for M. fragans, and limonene, $\beta$-cimene and $\alpha$-pinene for $V$. surinamensis). Nevertheless, the two last have sesquiterpene hydrocarbontype compounds as major constituents ( $\beta$-caryophyllene, $\alpha$-humulene, and $\alpha$-copaene for M. malabarica, and $\beta$-caryophyllene, linalool and $\alpha$-humulene for G. canarica). In this case, the essential oil from fruits of $I$. ulei was found to contain oxygenated sesquiterpene-type compounds as main constituents. It's known that, due to geographical position and seasonal variations (intrinsic and external factors), the content and composition of the oil is affected (the former had been demonstrated to the American Myristicaceae species $V$. surinamensis $\left.{ }^{17}\right)$. 
Table I. Percentage Composition of the fruit oil of Iryanthera ulei Warb.

\begin{tabular}{|c|c|c|c|c|c|}
\hline $\mathbf{R I}^{\mathbf{b}}$ & Compounds $^{2}$ & $\%$ & $\mathbf{R I}^{\mathbf{b}}$ & Compounds $^{\mathrm{a}}$ & $\%$ \\
\hline 813 & unknown $1^{c}$ & 2.0 & 1654 & $\alpha$-muurolol & 13.2 \\
\hline 833 & unknown $2^{c}$ & 0.3 & 1660 & $\alpha$-cadinol & 7.8 \\
\hline 838 & unknown $3^{c}$ & 0.5 & 1668 & unknown $7^{\mathrm{c}}$ & 7.1 \\
\hline 844 & unknown $4^{\mathrm{c}}$ & 1.2 & 1682 & guaia-3,10(14)-dien-11-ol & 1.2 \\
\hline 856 & unknown $5^{\mathrm{c}}$ & 1.9 & 1691 & khusinol & 0.4 \\
\hline 942 & $\alpha$-pinene & 0.9 & 1697 & eudesma-4(15),7-dien-1 $\beta$-ol & 1.8 \\
\hline 984 & $\beta$-pinene & 0.3 & 1719 & cedroxide & 0.5 \\
\hline 1039 & limonene & 3.3 & 1734 & oplopanone & 3.7 \\
\hline 1388 & $\alpha$-copaene & 0.3 & 1753 & cedrenol acetate & 1.0 \\
\hline 1404 & $\beta$-elemene & 1.5 & 1779 & 14-hydroxy- $\alpha$-muurolene & 0.8 \\
\hline 1436 & $\beta$-caryophyllene & 2.7 & 1818 & epi- $\alpha$-bisabolol acetate & 0.2 \\
\hline 1469 & $\alpha$-humulene & 0.8 & 1829 & cyclopentadecanolide* & 0.6 \\
\hline 1495 & germacrene D & 1.5 & 1840 & nuciferol acetate & 1.3 \\
\hline 1507 & $\gamma$-amorphene & 0.9 & 1848 & unknown $8^{c}$ & 0.1 \\
\hline 1512 & $\alpha$-muurolene & 0.9 & 1871 & lanceol acetate & 0.8 \\
\hline 1527 & $\gamma$-cadinene & 0.9 & 1875 & $\beta$-santalol acetate & 1.2 \\
\hline 1529 & $\delta$-cadinene & 0.9 & 1879 & unknown $9^{c}$ & 0.5 \\
\hline 1537 & zonarene & 2.7 & 1908 & unknown $10^{\mathrm{C}}$ & 0.7 \\
\hline 1550 & $\alpha$-cadinene & 0.2 & 1960 & unknown $11^{\mathrm{c}}$ & 1.1 \\
\hline 1565 & unknown $6^{\mathrm{c}}$ & 0.2 & 1969 & unknown $12^{\mathrm{c}}$ & 0.4 \\
\hline 1573 & $(E)$-nerolidol & 1.6 & 2097 & unknown $13^{c}$ & 0.8 \\
\hline 1585 & dendrolasin & 0.5 & - & unknown $14^{\mathrm{c}}$ & 1.5 \\
\hline 1596 & spathulenol & 12.1 & - & unknown $15^{c}$ & 0.3 \\
\hline 1599 & globulol & 2.5 & & & \\
\hline 1606 & viridiflorol & 0.3 & \multicolumn{2}{|c|}{ Monoterpenes hydrocarbons(\%) } & $3(4,6 \%)$ \\
\hline 1619 & guaiol & 4.0 & \multicolumn{2}{|c|}{ Sesquiterpenes hydrocarbons(\%) } & $11(13,3 \%)$ \\
\hline 1624 & 1,10-di-epi-cubenol & 3.4 & \multicolumn{2}{|c|}{ Oxygenated sesquiterpenes(\%) } & $18(54,0 \%)$ \\
\hline 1627 & 1-epi-cubenol & 0.9 & \multicolumn{2}{|c|}{ Sesquiterpenones(\%) } & $1(3,7 \%)$ \\
\hline 1633 & eremoligenol & 0.4 & \multicolumn{2}{|c|}{ Sesquiterpenlactones(\%) } & $1(0,6 \%)$ \\
\hline 1640 & allo-aromadendrene epoxide & 2.5 & \multicolumn{2}{|c|}{ Acetylated sesquiterpenes(\%) } & $5(4,3 \%)$ \\
\hline 1645 & epi- $\alpha$-cadinol & 0.2 & \multicolumn{2}{|c|}{ Unknown(\%) } & $15(18,5 \%)$ \\
\hline \multicolumn{6}{|c|}{ 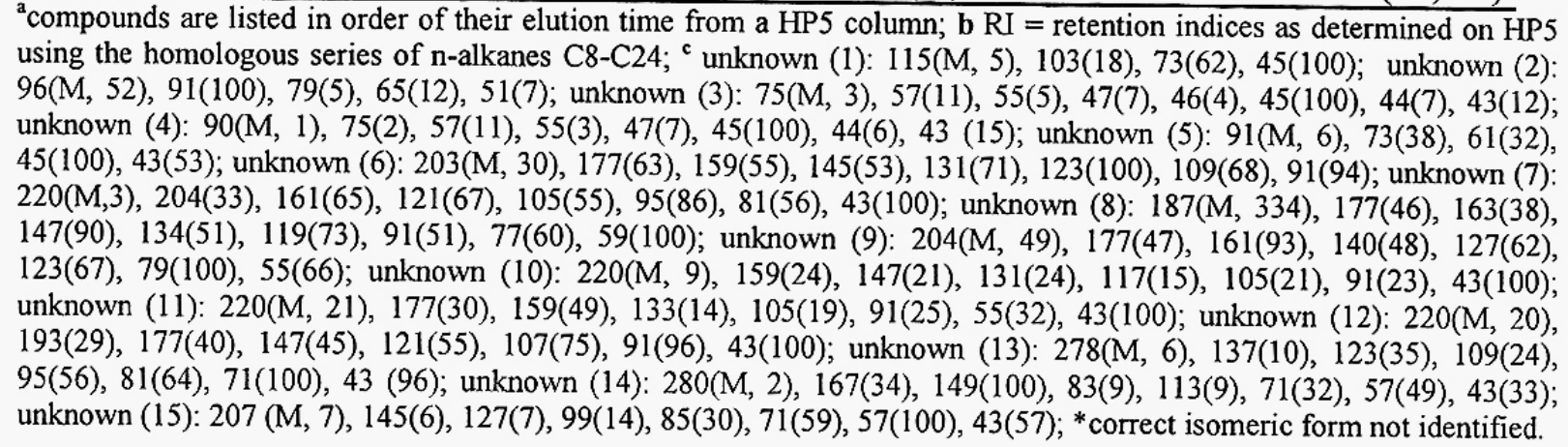 } \\
\hline
\end{tabular}


The results for antibacterial activity of essential oil are exposed in figure 1. S. aureus was found to be the most sensitive microorganism (about $53 \%$ growth inhibition) which is comparable to the standard antibiotic kanamycin (about $60 \%$ growth inhibition), whilst the \% growth inhibition against $E$. faecalis was $35 \%$. The oil was found to be totally ineffective against $E$. coli, however the standard antibiotic ampicillin showed a $40 \%$ growth inhibition toward this strain. Although the S. typhimurium MS7953 strain is known to be more sensitive, ${ }^{22}$ the oil showed similar growth inhibition value on comparing with the activity against the S. typhimurium 14028 S virulent strain.

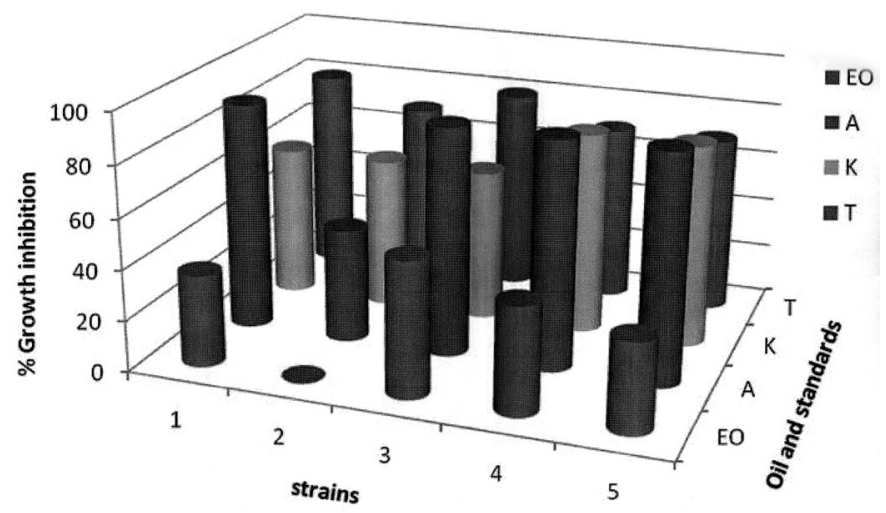

Figure 1. Antibacterial activity against some Gram-positive and negative bacteria of I. ulei essential oil. EO: essential oil; A: ampicillin; K: kanamycin; T: tetracycline; 1: E.faecalis S29212; 2: E.coli 25922; 3: S.aureus 6538; 4: S.typhimurium 14028S; 5: S. typhimurium MS7953

In conclusion, the essential oil from fruits of I. ulei can be taken as an excellent source of oxygenated sesquiterpene-type compounds which were characterized by means of GC-MS, containing $\alpha$-muurolol (13.2\%), spathulenol $(12.1 \%), \alpha$-cadinol $(7.8 \%)$, guaiol $(4.0 \%)$, oplopanone $(3.7 \%), 1,10$-diepicubenol (3.4\%) and limonene (3.3\%) as main components. In addition, the oil was found to have potential to inhibit the growth of $S$. aureus along other bacteria tested, but it was ineffective against $E$. coli, and non-selective between virulent and mutant strains for S. typhimurium. These results are in accordance with the colombian traditional medicine uses for this plant.

\section{ACKNOWLEDGEMENT}

We thank Dr. Sci. C. Osorio and M. S. Franco for their support in GC and GC/MS and Chemistry Department at Universidad Nacional de ColombiaBogotá for financing this work. Our gratitude is extended to Dr. Sci. J. M. Lozano for the antibacterial assay at Fundación Instituto de Inmunología de Colombia (FIDIC), Bogotá.

\section{REFERENCES}

1. A.C. Smith, R.P. Wodehouse, Brittonia, 2, 393, (1937).

2. R.E. Schultes, B. Holmstedt, Lloydia, 34, 61, (1971).

3. M. M. Herrera. La familia Myristicaceae: posibilidades de uso múltiple y sostenido en bosques húmedos tropicales de Colombia. Graduate thesis in Biology. Universidad Nacional de Colombia. Departamento de Biología. 1994.

4. O. R. Gottlieb, J. Ethnopharmacol. 1, 309, (1979).

5. R. Rojas, B. Bustamante, J. Bauer, I. Fernández, J. Albán, O. Lock, J. Ethnopharmacol. 88, 199, (2003).

6. P.C. Vieira, M. Yoshida, O.R. Gottlieb, H.F. Paulino Filho, T.J. Nagem, R. Braz Filho, Phytochemistry, 22, 711, (1983).

7. L.M. Conserva, M. Yoshida, O.R. Gottlieb, J.C. Martínez V., H.E. Gottlieb, Phytochemistry, 29, 3911, (1990).

8. L.M. Conserva, M. Yoshida, O.R. Gottlieb, Phytochemistry, 29, 3986, (1990).

9. M. Hadad, J. A. Zygadlo, B. Lima, M. Derita, G. E. Feresin, S. A. Zacchino, A. Tapia. J. Chil. Chem. Soc. 52, 1186, (2007).

10. R. M. Pérez Gutiérrez, H. Hernández Luna, S. Hernández Garrido. J. Chil. Chem. Soc. 51, 883, (2006).

11. H. Cao, M. J. Ji, H. X. Wang. J. Chil. Chem. Soc. 52, 1088, (2007).

12. R. P. Adams, Identification of Essential Oil Components by Gas Chromatography/Quadrupole Mass Spectroscopy. Allured Publishing Corporation, Carol Stream, IL, 2001.

13. N. Kondjoyan, J.L. Berdagué, A compilation of Relative Retention Indices for the Analysis of Aromatic Compounds. First Edition, Laboratoire Flaveur, Ed., Clermont-Ferrand, France, 1996.

14. W. Jennings, T. Shibamoto, Qualitative Analysis of Flavor and Fragance Volatiles by Glass Capillary Gas Chromatography. Academic Press, NY, 1980.

15. R. Lehrer, M. Rosenman, R. Jackson, P. Einsenhauer, J. Immunol. Methods. 137, 167, (1991)

16. N.P. Lopes, M.J. Kato, E.H. de A. Andrade, J.G.S. Maia, M. Yoshida, A.R. Planchar, A.M. Katzin, J. Ethnopharmacol. 67, 313, (1999).

17. N.P. Lopes, M.J. Kato, E.H. de A. Andrade, J.G.S. Maia, M. Yoshida, Phytochemistry, 46, 689, (1997).

18. Q. Qiu, G. Zhang, X. Sun, X. Liu, Zhong Yao Cai, 27, 823, (2004).

19. Y. Wang, XW. Yang, HY. Tao, HX. Liu, Zhongguo Zhong Yao Za Zhi, 29, 339, (2004)

20. H.J. D. Dorman, S. G. Deans, J. Essent. Oil Res. 16, 145, (2004).

21. B. Sabulal, R. Kurup, B. Sumitha, G. Varughese. J. Essent. Oil Res. 19, 323, (2007).

22. P. I. Fields, R. V. Swanson, C. G. Haidaris, F. Heffron. Proc. Natl. Acad. Sci. 83, 5189, (1986). 